Benchmarks

\section{Mild Hypothermia Inhibits Differentiation of Human Embryonic and Induced Pluripotent Stem Cells}

\author{
Glenn S. Belinsky and Srdjan D. Antic \\ Department of Neuroscience, University of Connecticut Health Center, \\ Farmington, CT, USA.
}

BioTechniques 55:79-82 (August 2013) doi 10.2144/000114065

Keywords: temperature; culture; unwanted differentiation; spontaneous differentiation; cold-inducible gene

Culture of pluripotent stem cells at $35^{\circ} \mathrm{C}$ strikingly reduces unwanted spontaneous differentiation duringhESC and iPSC maintenance compared with $37^{\circ} \mathrm{C}$. Growth at $35^{\circ} \mathrm{C}$ did not affect expression of pluripotency mRNAs nor induce expression of cold-inducible genes. Colony size was somewhat reduced at $35^{\circ} \mathrm{C}$. Thus, growth at $35^{\circ} \mathrm{C}$ is a convenient, simple method to reduce the labor of removing spontaneously differentiated colonies when maintaining pluripotent cells.

Hand, foot, and forehead temperatures are well below $37^{\circ} \mathrm{C}$, and scrotal hypothermia is critical for normal spermatogenesis (1-3). Growth at $31.5^{\circ} \mathrm{C}$ increases proliferation ratios in neural cell precursors $(4,5)$. T lymphocyte differentiation into effector cells is decreased at $33^{\circ} \mathrm{C}(6)$, while culture at $30^{\circ} \mathrm{C}$ inhibits myogenic differentiation of myoblasts (7). A slight lowering of body temperature has been reported to increase life span in transgenic mice $(8,9)$. Extreme examples of the beneficial effects of hypothermia can be found in hibernating animals, where core temperature typically drops to $5^{\circ} \mathrm{C}(10)$. Despite the known biological effects of temperature variation, there has been no published temperature optimization for human embryonic stem cell (hESC) or human induced pluripotent stem cell (hiPSC) growth in culture.

We hypothesize that low physiological temperatures will slow unwanted differentiation of stem cells, which may reduce the manual labor of removing spontaneously differentiated colonies during stem cell maintenance. To test the effects of hypothermia, hESCs and hiPSCs were maintained on mouse embryonic fibroblast (MEF) feeder layers in DMEM/ F12+KOSR+bFGF using standard protocols (11). Human ESC line H9 was obtained from the University of Connecticut-Wesleyan University Stem Cell Core, and the human iPSC-15 line was obtained from the Albert Einstein College of Medicine (12). Stem cell colonies were disassociated with collagenase and resuspended in growth media. Then all wells were seeded identically in six-well plates on MEFs (passage $=4$ ). Colonies were simultaneously grown at $35^{\circ} \mathrm{C}$ or $37^{\circ} \mathrm{C}$ in separate incubators. Temperatures were verified with a NIST traceable thermometer, and the 3 thermometers used to monitor temperatures in the incubators were within $0.5^{\circ} \mathrm{C}$ of each other. Carbon dioxide was monitored by Fyrite 10-5000 (Bacharach, Kensington, PA). Results did not depend on the incubator used. Normal and differentiated colonies were counted, and the differentiated colonies were removed daily by aspiration, a standard procedure in stem cell culture. Normal colonies of both cell lines appeared uniform and dense across the entire colony and displayed smooth edges. The loss a of defined colony boundary and the presence of elongated cells at the edge of a colony was the typical pattern of differentiation for both cell lines (Figure 1A, df).

Normal and differentiated colonies were found at both temperatures with no differences in the morphology of normal colonies (Figure 1A-B). Growth rates were higher at $37^{\circ} \mathrm{C}$, as evidenced by larger colonies after 7 days (Figure 1B). Seven days after seeding, the mean colony diameter at $37^{\circ} \mathrm{C}$ was $268 \pm 31 \mu \mathrm{m}$ (mean $\pm \mathrm{SEM}$; $n=28$ ), while mean colony size at $35^{\circ} \mathrm{C}$ was $177 \pm 10 \mu \mathrm{m}(n=55)$. Maintenance at $35^{\circ} \mathrm{C}$ caused a highly significant reduction in the numbers of differentiated colonies and ratios of differentiated/total colonies in both hESCs and hiPSCs (Figure 1C and D). At day 4, H9 hESCs produced an average of 32 differentiated colonies per well, while maintenance at $35^{\circ} \mathrm{C}$ produced only 2 differentiated colonies per well (Figure 1C). Therefore, culture at $35^{\circ} \mathrm{C}$ required far less manual removal of differentiated colonies. After 6-7 days, final numbers of undifferentiated colonies per well were significantly higher at $35^{\circ} \mathrm{C}$ compared with $37^{\circ} \mathrm{C}$ : for $\mathrm{H} 9 \mathrm{hESCs}, 37^{\circ} \mathrm{C}(80 \pm 5.4), 35^{\circ} \mathrm{C}$ $(146 \pm 5.7) P<0.00001$; for iPSC-15 cells, $37^{\circ} \mathrm{C}(8.7 \pm 2.0), 35^{\circ} \mathrm{C}(22 \pm 1.5) P<0.0005$ (by Student's $t$-test). Reduced differentiation at low temperature is consistent with several reports using lineage committed progenitors (4-7). Because some researchers only remove differentiated colonies immediately before passaging, we also monitored spontaneous differentiation without removing colonies (no weeding). H9 hESCs or iPSC-15 cells were seeded on MEFs (passage $=3$ ) and all colonies were counted daily. While the total number of colonies per well was similar, fewer differentiated colonies were found at $35^{\circ} \mathrm{C}$ compared with $37^{\circ} \mathrm{C}$ (Figure $1 \mathrm{E}$ and $\mathrm{F}$ ).

We verified continued expression of several pluripotency markers by RT-PCR at $35^{\circ} \mathrm{C}$. RNA was extracted using Trizol (Invitrogen, Carlsbad, CA), cDNA was made with SuperscriptIII (Invitrogen), and PCR was performed with GoTaq (Promega, Madison, WI) according to the manufacturers' recommendations. We found no significant difference in mRNA levels for the pluripotency markers OCT4, SOX2 and NANOG (Figure 2A).

The neuroprotective effects of mild hypothermia are reportedly due to up-regulation of the cold-inducible transcription factors CIRP or RBM3 $(5,13)$. CIRP and RBM3 are expressed in rodent testes and brain, and are markedly up-regulated by some environmental conditions (14-16). These two cold-stress inducible markers were examined to determine if they may be up-regulated at $35^{\circ} \mathrm{C}$. We saw no difference in expression of CIRP and RBM3 mRNA at $35^{\circ} \mathrm{C}$ as compared to $37^{\circ} \mathrm{C}$ (Figure $2 \mathrm{~A}$ ).

\title{
Method summary:
}

Here we demonstrate that growth of embryonic and induced pluripotent stem cells at a lower temperature $\left(35^{\circ} \mathrm{C}\right)$ reduces spontaneous differentiation in culture without any adverse effects on the cells. This methodology can be used to reduce the labor associated with stem cell experimentation. 
A
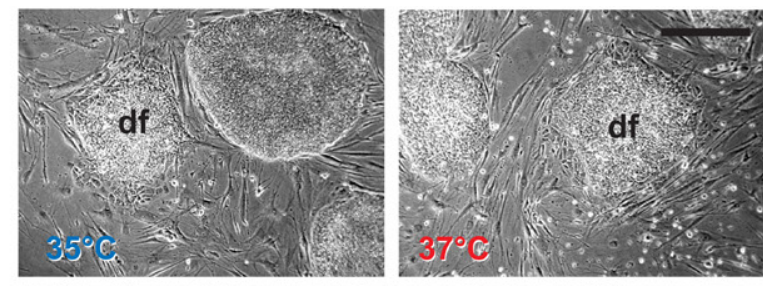

B
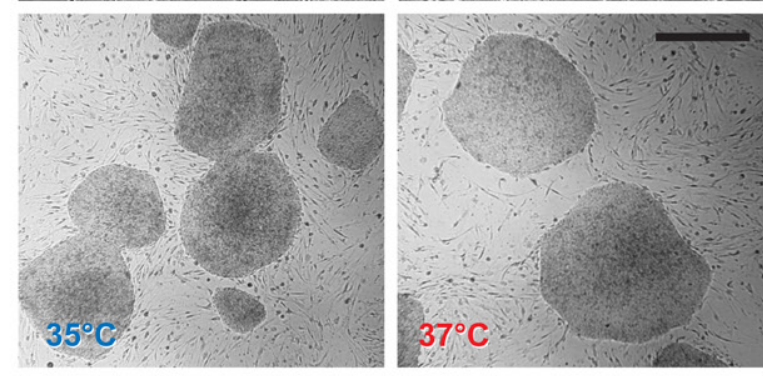

C
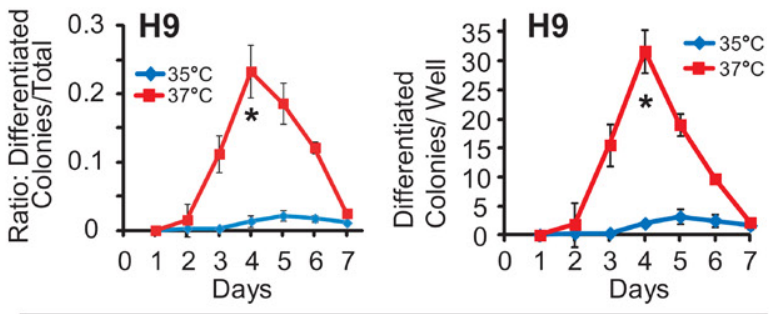

D
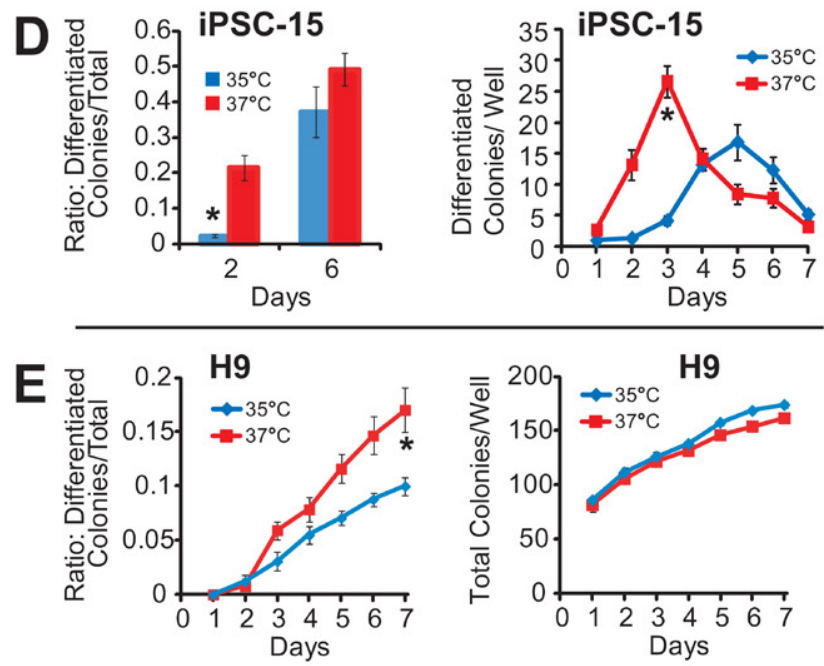

\section{$\mathbf{F}$}
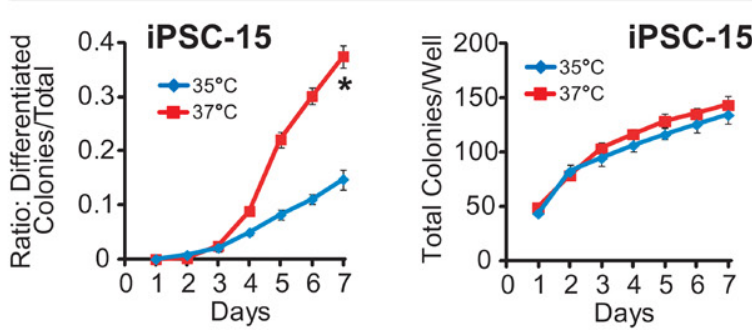

Figure 1. Spontaneous differentiation of human embryonic stem cell line $\mathrm{H9}$ or induced pluripotent stem cell line iPSC-15 under mild hypothermia $\left(3^{\circ} \mathrm{C}\right)$. (A) Phase contrast images of differentiated (df) and normal $\mathrm{H} 9$ colonies 5 days after seeding at the indicated temperatures (bar $=300 \mu \mathrm{m}$ ). (B) Normal H9 colonies 7 days after seeding at the indicated temperatures (bar $=1 \mathrm{~mm}$ ). (C) Time course showing ratio of differentiated $\mathrm{H} 9$ to total colony number, and per diem count of differentiated $\mathrm{H} 9$ colonies per well, at two temperatures. Differentiated colonies were removed daily ("weeding"). Sub-optimal MEFs (P > 4) were used. This experiment has been repeated three times with qualitatively similar results. (D) Same as in C, except iPSC-15 cells were used. (E-F) Spontaneous differentiation ratios without daily removal of bad colonies (without weeding) for H9 (E) and iPSC-15 (F). Cumulative numbers of differentiated and total colonies are shown. $n=6$ wells per point for (C)-(E). ${ }^{*} P<0.01$ Student's t-test.
The following primers were used for RT-PCR (5' to $\left.3^{\prime}\right)$ :

OCT4:

AGTTTGTGCCAGGGTTTTTG, ACTTCACCTTCCCTCCAACC.

SOX2:

AGTCTCCAAGCGACGAAAAA, TTTCACGTTTGCAACTGTCC. NANOG:

TTTGGAAGCTGCTGGGGAAG, GATGGGAGGAGGGGAGAGGA.

ACTB:

CCTCGCCTTTGCCGATCC, GATGCCGTGCTCGATGGGGT.

CIRP:

CAAAGTACGGACAGATCTCTGA, CGGATCTGCCGTCCATCTA.

\section{RBM3:}

CTTCAGCAGTTTCGGACCTA, ACCATCCAGAGACTCTCCGT.

Colonies maintained at $35^{\circ} \mathrm{C}$ were capable of producing healthy neurons when switched to $37^{\circ} \mathrm{C}$ and exposed to our standard dopamine neuron differentiation protocol (11). Immunofluorescent labeling with the neuronal marker TUJ1 and catecholaminergic marker tyrosine hydroxylase $(\mathrm{TH})$ revealed an abundance of dopaminergic neurons (Figure 2B). Neurons derived from $35^{\circ} \mathrm{C}$ stem cell colonies had resting membrane potential $(-28$ $\pm 1.2 \mathrm{mV}, n=72)$, input resistance $(2.0 \pm 0.2$ $\mathrm{G} \Omega$ ) similar to those published for neurons derived from $37^{\circ} \mathrm{C}$ stem cell colonies (11). Neurons also fired action potentials in response to somatic current injection (Figure 2C). These data indicate the presence of ectoderm. Next, we asked if endoderm and mesoderm were formed. H9 hESCs were maintained at $35^{\circ} \mathrm{C}$ for 10 days, then embryoid bodies were cultured at $37^{\circ} \mathrm{C}$ for 4 days. Consistent with normal gastrulation, AFP (endoderm marker) and CSX (mesoderm marker) mRNAs were present in the embryoid bodies (Figure 2D) (17). Primer sequences used were ( $5^{\prime}$ to $\left.3^{\prime}\right)$ :

AFP:

AGAACCTGTCACAAGCTGTG, GACAGCAAGCTGAGGATGTC.

CSX:

ACGCCCTTCTCAGTCAAAGAC, CGCGCACAGCTCTTTCTTTT.

Although we found no changes in the pluripotency markers or cold-inducible transcription factors we examined, it is possible that additional cold-inducible factors exist in pluripotent cells. Other potential mechanisms by which low physiological temperature reduces differentiation of pluripotent stem cells may be related to molecular interactions. Media components such as KOSR or bFGF may have longer half-lives at $35^{\circ} \mathrm{C}$ compared with $37^{\circ} \mathrm{C}$. A $2^{\circ} \mathrm{C}$ temperature change may affect enzyme activities, transcription factor binding, membrane properties, metabolite 
A
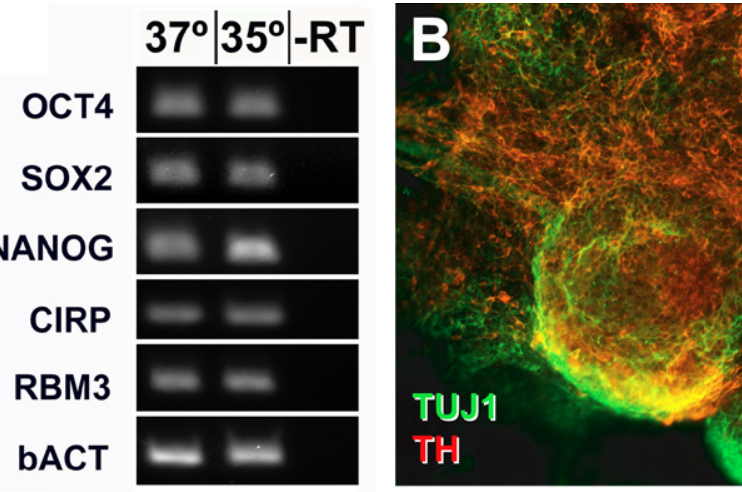

C

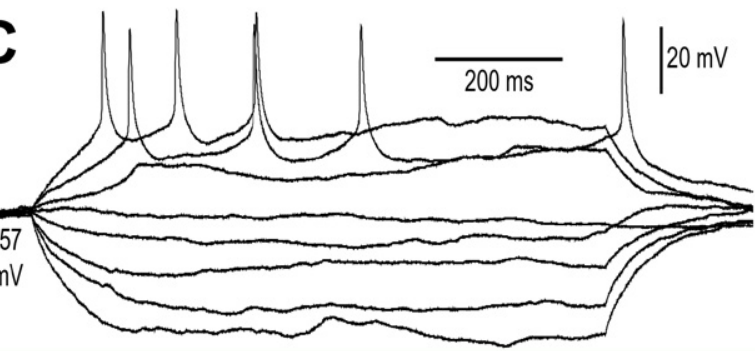

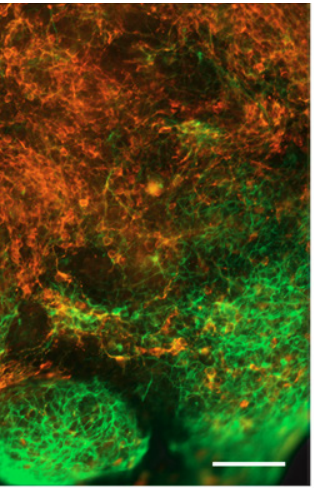

D

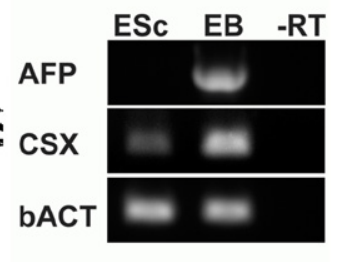

Figure 2. Normal stem cell properties of the hypothermic colonies. (A) Gene expression by RT-PCR for $\mathrm{H} 9 \mathrm{hESC}$ maintained at either $37^{\circ} \mathrm{C}$ or $35^{\circ} \mathrm{C}$. Pluripotency markers (OCT4, SOX2, NANOG) and coldinducible mRNAs (CIRP, RBM3) were examined during the exponential phase of PCR. $-\mathrm{RT}=$ no reverse transcriptase controls. NANOG was repeated $3 x$ and no significant difference was found. (B) Low power image of neurons differentiated at $37^{\circ} \mathrm{C}$ from hESCs maintained at $35^{\circ} \mathrm{C}$. Green: pan-neuronal marker TUJ1, red: dopaminergic neuron marker TH. Bar $=100 \mu \mathrm{m}$. (C) Whole-cell recording of neuronal membrane responses to a series of somatic current injections showing action potentials; first current pulse $=-20 \mathrm{pA}$; subsequent pulses $+5 \mathrm{pA}$ step increase. The neuron was kept hypopolarized at $-57 \mathrm{mV}$ with bias DC current. Natural resting potential immediately upon patching $=-30 \mathrm{mV}$. (D) Gene expression by RT-PCR for endoderm marker (AFP), mesoderm marker (CSX) and housekeeping gene bACT, in H9 hESC colonies (ESc) or 4-day embryoid bodies (EB). $-\mathrm{RT}=$ no reverse transcriptase controls.

stabilities, or other cellular processes that combine to produce the observed effect.

Our data demonstrate a practical and low-cost method for reducing differentiation of stem cell colonies, given the availability of a $35^{\circ} \mathrm{C}$ incubator. This labor saving technique does not appear to alter the pluripotent nature of the cells, or their ability to differentiate when switched back to $37^{\circ} \mathrm{C}$. We have maintained hESCs and iPSCs for 2 months at $35^{\circ} \mathrm{C}$ with no change in morphology, although we notice better seeding efficiency at $37^{\circ} \mathrm{C}$. In addition, published reports suggest that there may be less accumulation of DNA damage under mild hypothermia $(18,19)$.

\section{Acknowledgments}

The authors thank Erika Pedrosa and Herbert M. Lachman for providing the iPSC-15 line. This study was supported by Connecticut Innovations grant 09-SCA-UCHC-13. Electrophysiological measurements were performed in the Stem Cell Physiology and Chemistry Core, which is supported by Connecticut Innovations grant SCD-01-2009.

\section{Competing interests}

The authors declare no competing interests.

\section{References}

1. Parvinen, M. 1973. Observations on freshly isolated and accurately identified spermatogenic cells of the rat. Early effects of heat and short-time experimental cryptorchidism. Virchows Arch B Cell Pathol. 13:38-47.

2. Mieusset, R., L. Bujan, C. Mondinat, A. Mansat, F. Pontonnier, and H. Grandjean. 1987. Association of scrotal hyperthermia with impaired spermatogenesis in infertile men. Fertil. Steril. 48:1006-1011.

3. Kräuchi, K. and A. Wirzjustice. 1994. CircadianRhythm of Heat-Production, Heart-Rate, and Skin and Core Temperature under Unmasking Conditions in Men. Am.J. Physiol.267:R819-R829.

4. Imada, S., M. Yamamoto, K. Tanaka, C. Seiwa, K. Watanabe, Y. Kamei, S. Kozuma, Y. Taketani, H. Asou. 2010. Hypothermia-induced increase of oligodendrocyte precursor cells: Possible involvement of plasmalemmal voltage-dependent anion channel 1.J. Neurosci. Res. 88:3457-3466.

5. Saito, K., N. Fukuda, T. Matsumoto, Y. Iribe, A. Tsunemi, T. Kazama, C. Yoshida-Noro, and N. Hayashi. 2010. Moderate low temperature preserves the stemness of neural stem cells and suppresses apoptosis of the cells via activation of the cold-inducible RNA binding protein. Brain Res. 1358:20-29.
6. Mace, T.A., L. Zhong, C. Kilpatrick, E. Zynda, C.T. Lee, M. Capitano, H.Minderman, and E.A. Repasky. 2011. Differentiation of CD8+ T cells into effector cells is enhanced by physiological range hyperthermia. J. Leukoc. Biol. 90:951-962.

7. Shima, A., J. Pham, E. Blanco, E.R. Barton, H.L. Sweeney, and R. Matsuda. 2011. IGF-I and vitamin $\mathrm{C}$ promote myogenic differentiation of mouse and human skeletal muscle cells at low temperatures. Exp. Cell Res. 317:356-366.

8. Conti, B., M. Sanchez-Alavez, R. WinskySommerer, M.C. Morale, J. Lucero, S. Brownell, V. Fabre, S. Huitron-Resendiz, etal.2006. Transgenic mice with a reduced core body temperature have an increased life span. Science 314:825-828.

9. Carrillo, A.E. and A.D. Flouris. 2011. Caloric restriction and longevity: Effects of reduced body temperature. Ageing Res. Rev. 10:153-162.

10.Geiser, F. 2004. Metabolic rate and body temperature reduction during hibernation and daily torpor. Annu. Rev. Physiol. 66:239-274.

11. Belinsky, G.S., A.R. Moore, S.M. Short, M.T. Rich, and S.D. Antic. 2011. Physiological Properties of Neurons Derived from Human Embryonic Stem Cells using a dbcAMP-based Protocol. Stem Cells Dev. 20:1733-1746.

12. Pedrosa, E., V. Sandler, A. Shah, R. Carroll, C. Chang, S. Rockowitz, X. Guo, D. Zheng, and H.M. Lachman. 2011. Development of patientspecific neurons in schizophrenia using induced pluripotent stem cells. J. Neurogenet. 25:88-103.

13.Chip, S., A. Zelmer, O.O. Ogunshola, U. Felderhoff-Mueser, C. Nitsch, C. Buhrer, and S. Wellmann. 2011. The RNA-binding protein RBM3 is involved in hypothermia induced neuroprotection. Neurobiol. Dis. 43:388-396.

14.Nishiyama, H., J.H. Xue, T. Sato, H. Fukuyama, N. Mizuno, T. Houtani, T. Sugimoto, and J. Fujita. 1998. Diurnal change of the cold-inducible RNA-binding protein (Cirp) expression in mouse brain. Biochem. Biophys. Res. Commun. 245:534-538.

15. Wellmann, S., C. Buhrer, E. Moderegger, A. Zelmer, R. Kirschner, P. Koehne, J. Fujita, and K. Seeger. 2004. Oxygen-regulated expression of the RNA-binding proteins RBM3 and CIRP by a HIF-1independent mechanism. J. Cell Sci. 117:1785-1794.

16.Lleonart, M.E. 2010. A new generation of proto-oncogenes: Cold-inducible RNA binding proteins. Biochim Biophys Acta. 1805:43-52.

17. Bettiol, E., L. Sartiani, L. Chicha, K.H. Krause, E. Cerbai, and M.E. Jaconi. 2007. Fetal bovine serum enables cardiac differentiation of human embryonic stem cells. Differentiation 75:669-681.

18. Mayer, P.J., M.O. Bradley, and W.W. Nichols. 1987. The Effect of Mild Hypothermia (34 Degrees C) and Mild Hyperthermia (39 Degrees C) on DNA Damage, Repair and Aging of Human-Diploid Fibroblasts. Mech. Ageing Dev. 39:203-222.

19. Ji, X., Y.M. Luo, F. Ling, R.A. Stetler, J. Lan, G.D. Cao, and J. Chen. 2007. Mild hypothermia diminishes oxidative DNA damage and pro-death signaling events after cerebral ischemia: a mechanism for neuroprotection. Front. Biosci. 12:1737-1747.

Received 29 November 2012; accepted 03 June 2013.

Address correspondence to Glenn S. Belinsky, Department of Neuroscience University of Connecticut Health Center, Farmington, CT. E-mail: belinsky@uchc.edu

To purchase reprints of this article, contact: biotechniques@fosterprinting.com 